\title{
Konsep Pendidikan Agama Islam Dalam Tinjauan Hadits (Studi Analisis Tentang Hadits-Hadits Pendidikan)
}

\section{Muhamad Basyrul Muvid}

Universitas Dinamika Surabaya

Jl. Raya Kedung Baruk No 98, Kecamatan Rungkut, Kota Surabaya, Jawa Timur e-mail: muvid@dinamika.ac.id

\begin{tabular}{|c|c|c|}
\hline Diterima: & Revisi: & Disetujui: \\
11 Desember 2019 & 22 Januari 2020 & 07 Maret 2020 \\
\hline DOI: & \multicolumn{2}{|c|}{ the DOI 10.32332/tarbawiyah.v4i1.1733 } \\
\hline
\end{tabular}

\begin{abstract}
The position of the hadith in Islamic religious education becomes a basis and foundation for the concepts, framework and design of Islamic religious education, bearing in mind the hadith provides a more concrete rationale regarding the application of various activities that must be developed in the Muslim life and life framework. The concept of Islamic education in the review of educational hadiths covered includes: basic education, learning obligations, educational objectives, educational institutions, learning materials (education), learning methods, educators (teachers), students (students), women's education and evaluation learning. These ten became the basic framework in building Islamic religious education in accordance with the hadith of the Prophet.
\end{abstract}

Keyword Position of the Hadith, Concept of Islamic Education, Analysis of Islamic Educational Hadiths

\begin{abstract}
Abstrak Kedudukan hadis dalam pendidikan agama Islam menjadi dasar dan fondasi bagi konsep, kerangka kerja dan desain pendidikan agama Islam, mengingat hadis memberikan alasan yang lebih konkret mengenai penerapan berbagai kegiatan yang harus dikembangkan dalam kehidupan Muslim. dan kerangka hidup. Konsep pendidikan Islam dalam tinjauan hadits pendidikan yang dibahas meliputi: pendidikan dasar, kewajiban belajar, tujuan pendidikan, lembaga pendidikan, materi pembelajaran (pendidikan), metode pembelajaran, pendidik (guru), siswa (siswa), pendidikan perempuan dan pembelajaran evaluasi. Kesepuluh ini menjadi kerangka dasar dalam membangun pendidikan agama Islam sesuai dengan hadits Nabi.
\end{abstract}

Kata Kunci Kedudukan Hadits, Konsep Pendidikan Islam, Analisa Hadits-Hadits Pendidikan Islam 


\section{A. Pendahuluan}

Hadits merupakan salah satu dasar pendidikan Islam selain alQur'an. Di mana dasar adalah sesuatu yang penting bagi sebuah kerangka pendidikan Islam. Karena pada hakikatnya dasar sebagai landasan untuk berdirinya sesuatu. Fungsi dasar ialah memberikan arah kepada tujuan yang akan dicapai sekaligus sebagai modal yang pokok bagi berdirinya sebuah lembaga pendidikan Islam. Dasar pendidikan Islam didasarkan pada falsafah hidup umat Islam dan tidak didasarkan kepada falsafah hidup suatu negara. Falsafah hidup umat Islam itu sendiri terletak pada dua sumber pokok yakni al-Qur'an dan al Sunnah (al hadits). ${ }^{1}$

Hal tersebut menandakan bahwa hadits sebagai dasar, sumber dan acuan dalam kehidupan umat manusia, termasuk pada dunia pendidikan agama Islam. Oleh karenanya, pendidikan Islam harus senantiasa mengacu kepada sumber utamanya yakni al-Qur'an dan alHadits. Agar tujuan pendidikan Islam dapat dicapai dengan baik sehingga out put yang dihasilkan oleh lembaga pendidikan agama Islam menjadi out put yang saleh, berkompeten dan unggul baik dalam segi ilmu (pengetahuan), sikap dan keterampilan.

Dengan demikian, telaah hadits-hadist Nabi saw terkait pendidikan (hadits tarbawi) sangat penting untuk dilakukan untuk menyatukan konsep pendidikan Islam dengan sumber atau dasar dari pendidikan Islam itu sendiri yakni al-hadits. Artinya, konsep pendidikan Islam yang dibangun dan dirancang benar-benar sesuai dengan gagasan dan pondasi yang dipraktikkan oleh Rasulullah saw. Hal tersebut, untuk membuktikan bahwa pendidikan agama Islam adalah pendidikan berbasisis kenabian (ala Rasulullah saw).

\section{B. Kedudukan Hadits Dalam Pendidikan Agama Islam}

Selain sebagai sumber pedoman kedua setelah al-Qur'an dalam agama Islam, hadits juga sebagai dasar bagi pendidikan Islam. Ia memiliki kedudukan yang penting dalam kehidupan dan pemikiran Islam sangat penting, karena di samping memperkuat dan memperjelas berbagai persoalan dalam al-Qur'an, juga memberikan dasar pemikiran yang lebih konkret mengenai penerapan berbagai aktivitas yang mesti dikembangkan dalam kerangka hidup dan kehidupan umat Islam. Banyak hadits Nabi saw yang mempunyai relevansi kearah pemikiran

\footnotetext{
${ }^{1}$ Ramayulis, Ilmu Pendidikan Islam (Jakarta: Kalam Mulia, 2010), 121.
} 
dan implikasi langsung bagi pengembangan serta penerapan dunia pendidikan. ${ }^{2}$

Dari sini dapat dikatakan bahwa hadist secara kedudukan ia menempati posisi kedua setalah al-Qur'an, baik dalam dunia Islam itu sendiri sebagai pedoman umat Islam maupun dalam dunia pendidikan agama Islam. Karena sejatinya pendidikan agama Islam adalah bagian dari Islam itu sendiri yang fokus pada aspek pendidikan dan pengajaran. Dalam bahasa lain, hadist sebagai acuan dasar bagi pendidikan agama Islam dalam menerapkan, menjalankan dan mengaplikasikan pendidikan agama Islam di lembaga pendidikan secara langsung.

Kedudukan hadist sebagai representasi dari segala bentuk ucapan, perilaku dan ketetapan Nabi saw, yang dijadikan hujjah bagi pendidikan agama Islam, baik tentang tujuan, urgensi ilmu, pendidik, peserta didik, metode, materi ajar, maupun mengenai evaluasi pembelajaran dan lain sebagainya. Melalui contoh dan peraturanperaturan yang diberikan Nabi saw, merupakan suatu bentuk pelaksanaan pendidikan agama Islam yang dapat ditiru dan dijadikan sumber referensi teoritis maupun praktis. ${ }^{3}$

Kemudian, pribadi Nabi Muhammad saw menjadi gambaran seorang pendidik yang ideal, yang 'peka' terhadap objek yang dihadapinya. Artinya, Nabi tidak 'memukul rata' dan tidak disesuaikan dengan keinginannya pribadi. Namun, ia menyesuaikan dengan kapasitas, kemampuan dan kepribadian masing-masing peserta didik (para sahabat) dalam proses belajar mengajar, sehingga materi yang disampaikan bisa diterima dan dipahami dengan mudah oleh mereka.

Dengan demikian dapat disimpulkan bahwa hadits sebagai bentuk dari segala ucapan, perilaku, dan ketetapan Nabi Muhammad saw yang menjadi dasar utama setelah al-Qur'an dama dunia pendidikan Islam. Sehingga, menempatkannya ke dalam posisi yang utama dan penting dalam pendidikan Islam. Segala bentuk, konsep dan kerangka pendidikan Islam tidak lepas dari dasar pokoknya yakni alQur'an dan al Hadits. Oleh sebab itu, memahami hadist sangat penting,

2 NP. Aghnides, Muhammadan Theorities of Finance: With an Introduction to Muhammad Law and a Bibliography (New York: AMS Press, 1969), 35. Baca juga dalam Zakiah Darajat, Ilmu Pendidikan Islam (Jakarta: Bumi Aksara, 1996), 21.

3 Jalaluddin dan Usman Said, Filsafat Pendidikan Islam; Konsep dan Perkembangan Pemikirannya (Jakarta: Raja Grafindo Persada, 1994), 37.

Tarbawiyah: Jurnal Ilmiah Pendidikan :: Volume 04; Nomor 1, Juni 2020 
terlebih hadits-hadits tentang pendidikan Islam, hal tersebut untuk dijadikan pijakan oleh pelaku pendidikan Islam dalam menerapakan pendidikan ala Rasulullah saw.

\section{Konsep Pendidikan Agama Islam Dalam Tinjauan Hadits}

Konsep pendidikan agama Islam dalam tinjuan hadits ini sebagai langkah awal untuk mengetahui, memahami dan mengaplikasikan konsep tersebut ke dalam praktik pendidikan agama Islam di lingkungan dan lembaga pendidikan Islam. Di antara konsep pendidikan Islam dalam tinjauan hadith meliputi sepuluh unsur, yakni:

\section{Dasar Pendidikan Islam}

Untuk mempermudah pembahasan, berikut ini salah satu hadis Nabi yang diriwayatkan oleh Bukhari tentang dasar pendidikan Islam.

$$
\begin{aligned}
& \text { حدّثنا علي بن عبد الله حدثنا سفيان قال سألت الأعمش فقال عن زيد ابن وهب سمعت } \\
& \text { حذيفة يقول حدّثنا رسول الله ص م أنّ الأمانة نزلت من السماء في جذر القلوب الرجال }
\end{aligned}
$$

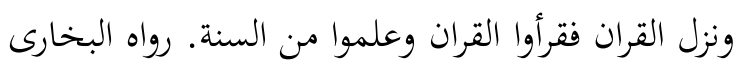

Telah menceritakan kepada kami Ali ibn Abdullah, menceritakan kepada kami Sufyan, ia berkata; 'Aku bertanya kepada A'masyi, ia berkata; 'Dari Zaid ibn Wahab, Aku mendengar Hudzaifah, ia berkata; 'Menceritakan kepada kami Rasul saw, bahwa amanah itu turun dari langit pada hati seseorang, dan diturunkan al-Qur'an, maka bacalah al-Qur'an dan pelajarilah Sunnah (Hadits)." (HR. Bukhari). ${ }^{4}$

Dalam hal ini memberikan kita gambaran bahwa al-Qur'an dan as-Sunnah harus dijadikan sebagai pegangan dan pedoman hidup, maka sangat tepat pendidikan Islam menjadikan al-Qur'an dan as-Sunnah sebagai dasar dan acuan dalam memberlakukan pendidikan Islam di lembaga pendidikan, baik di sekolah maupun di pesantren dan di lembaga lainnya. Jika suatu pendidikan terlebih pendidikan Islam dengan al-Qur'an dan as-Sunnah sebagai dasar dan acuan serta benar benar di implementasikan maka akan membentuk generasi-generasi Qur'ani dengan mengikuti (ittiba') Rasulullah saw dalam setiap tingkah

4 Abi Muhammad ibn Ismail ibn Ibrahim ibn al-Mughirah ibn Bardzabat alBukhari al-Ju'fi, Shahih al-Bukhari (t.tp: Dar Ibn Katsir, 1987), 1318. 
lakunya. Sehingga tujuan pendidikan Islam akan terlaksana dan tercapai dengan baik.

Hasan Langgulung dalam Abuddin Nata, ${ }^{5}$ mengatakan bahwa sumber atau dasar dari pendidikan Islam itu adalah al-Qur'an, asSunnah, ucapan sahabat, kemaslahatan umat, tradisi atau adat, dan hasil ijtihad para ahli. Selain itu, ada juga yang meringkas bahwa sumber atau dasar pendidikan Islam itu adalah al-Qur'an, Sunnah, sejarah dan filsafat. ${ }^{6}$ Namun, fokus kita dalam hal ini adalah mengenai al-Qur'an dan as-Sunnah sesuai dengan sabda Nabi saw di atas, dengan merujuk pendapat di atas, maka sudah jelas bahwa sumber atau dasar pendidikan Islam menempatkan al-Qur'an dan as-Sunnah pada tingkat pertama hal ini menandakan al-Qur'an dan as-Sunnah sebagai sumber atau dasar pendidikan Islam yang utama dan pokok. Sebagaimana Abdurrahman Saleh Abdullah mengatakan bahwa al-Qur'an merupakan kitab pendidikan, ${ }^{7}$ dan as-Sunnah sebagai sumber atau dasar pendidikan Islam dikuatkan dengan tugas Nabi saw sebagai guru ${ }^{8}$ yang membimbing umat menuju peradaban dan kebenaran sesuai dengan firman Allah dalam QS. al-Jumu'ah ayat 2: "Dialah yang mengutus kepada kaum yang buta huruf (ummi) seorang Rasul di antara mereka...." Dengan demikian, sangat tepat menjadikan al-Qur'an dan as-Sunnah sebagai dasar dalam pendidikan Islam, sehingga segala proses, tujuan, pengembangan, dan kegiatan dalam pendidikan dan pembelajaran mengacu pada ajaran-ajaran yang terkandung di dalam al-Qur'an dan as-Sunnah, sehingga al-Qur'an dan as-Sunnah melekat dan menyatu dalam jiwa mereka, baik bagi para pembuat kebijakan, pejabat terkait, pendidik, anak didik, orang tua dan masyarakat secara umum.

5 Hasan Langgulung, Beberapa Pemikiran tentang Pendidikan Islam (Bandung: al-Ma'arif, 1980), 35. Lihat juga Abdul Mujib dan Yusuf Mudzakkir, Ilmu Pendidikan Islam (Jakarta: Prenada Media, 2006), 31.

${ }^{6}$ Abuddin Nata, Filsafat Pendidikan Islam (Jakarta: Gaya Media Pratama, 2005), 59.

${ }^{7}$ Abdurrahman Saleh Abdullah, Teori-teori Pendidikan Berdasarkan al-Qur'an, terj. H.M. Arifin dari judul asli, Educational Theory: Qur'anic Outbook (Jakarta: Rineka Cipta, 2005), 20.

${ }^{8}$ Ziauddin Alawi, Pendidikan Islam pada Abad Pertengahan, terj. Abuddin Nata dari judul asli, Islamic Education in Middle Age (Bandung: Angakas, 2002), 67.

Tarbawiyah: Jurnal Ilmiah Pendidikan :: Volume 04; Nomor 1, Juni 2020 


\section{Kewajiban Belajar}

Sebenarnya banyak hadis tentang kewajiban belajar bagi kaum muslimin, salah satunya hadis Nabi yang diriwayatkan oleh Ibnu Majah;

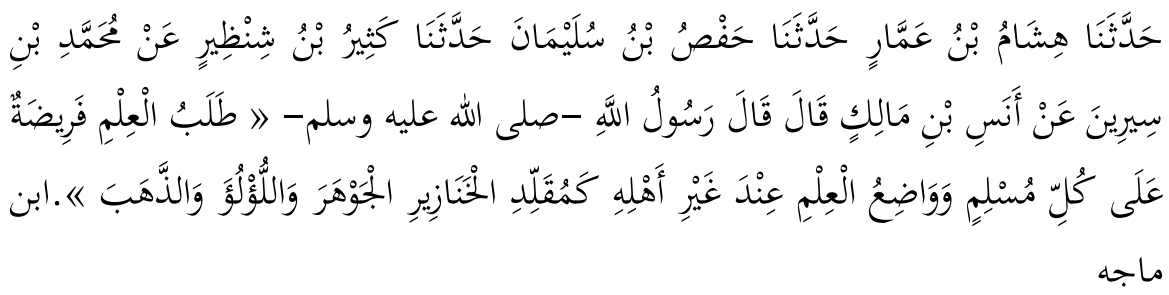

"Telah menceritakan kepada kami Hisyam bin Ammar, menceritakan kepada kmau Hafsha bin Sulaiman, menceritakan kepada kami Katsir bin Syindzir dari Mahmmad Sirin dari Anas bin Malik berkata, Rasullah saw bersabda: "Mencari ilmu wajib bagi setiap muslim (orang Islam). Dan meletakkan (menempatkan) ilmu pada yang bukan ahlinya maka seperti orang yang mengikuti seekor babi, permata, mutiara dan emas". (HR. Ibnu Majjah)

Menurut hemat penulis hadits tersebut dapat kita pahami dari dua sisi, yaitu pertama,bahwa mencari ilmu hukumnya wajib bagi setiap muslim, Karena dengan ilmu itulah manusia akan keluar dari kegelapan (kebodohan/kesesatan) dan Ilmu sebagai petunjuk hidup manusia sehingga menjadikannya sebagai makhluk yang mulia dan beradab. Bisa kita bayangkan bagaimana jadinya jika manusia itu tanpa ilmu, maka tentu mereka menjadi makhluk yang buta akan kebenaran dan akhlak sehingga kehidupannya berantakan dan kehidupan di dunia juga akan kacau (hancur).

Kedua, menempatkan ilmu bukan pada ahlinya seperti orang yang mengikuti babi, permata, mutiara dan emas. Artinya bahwa menyerahkan ilmu kepada orang yang bukan ahlinya itu sama halnya menempatkan sesuatu bukan pada tempatnya. Sehingga akan menimbulkan kerancuan dan kehancuran. Hal ini di perumpamakan seperti orang yang mengikuti kehidupan atau tingkah laku binatang (seekor babi), permata, mutiara, dan emas dalam hidupnya. Orang yang mengikuti pola hidup binatang (babi) dan terikat atau diperbudak oleh hiasan duniawi (permata, mutiara dan emas). Maka kehidupan akan gelap dan kehancuran akan menimpa orang tersebut. Karena sejatinya manusia harus bisa mengendalikan dan menempatkan dirinya pada 
tempat yang sesuai dengan aturan Allah swt., agar hidup bisa bermakna dan bahagia, sama dengan ilmu. Ilmu harus diserahkan kepada ahlinya, agar mereka bisa menggunakan ilmu tersebut sesuai dengan porsi dan tujuannya sehingga menimbulkan kemaslahatan dan kedamaian dalam kehidupan di muka bumi ini.

Prinsip wajib belajar menuntut ilmu sebagaimana hadits di atas, merupakan prinsip yang menekankan agar setiap orang Islam merasa bahwa meningkatkan kemampuan diri dalam bidang pengembangan wawasan ilmu pengetahuan, ketrampilan, pengalaman, intelektual, spiritual, dan sosial merupakan kewajiban yang harus dilaksankan.

Dengan prinsip ini, pendidikan Islam tidak menghendaki adanya orang Islam bodoh dan lemah, karena orang bodah dan lemah bukan saja menyusahkan dirinya, melainkan orang lain. Karena beratnya beban hidup akibat kebodohan akan ilmu pengetahuan, maka Ibnu Sina pernah berkata; 'bahwa akhlak yang paling buruk adalah kebodohan. ${ }^{9}$ Dengan demikian, sudah jelas bahwa menuntut ilmu adalah wajib bagi orang Islam baik laki-laki maupun perempuan. Islam menghendaki umatnya menjadi orang yang berilmu agar bisa mengapai kebahagian dunia dan akhirat.

\section{Tujuan Pendidikan Islam}

Berikut ini adalah hadis dari Rasulullah yang diriwayatkan oleh Ahmad tentang tujuan dari pendidikan Islam;

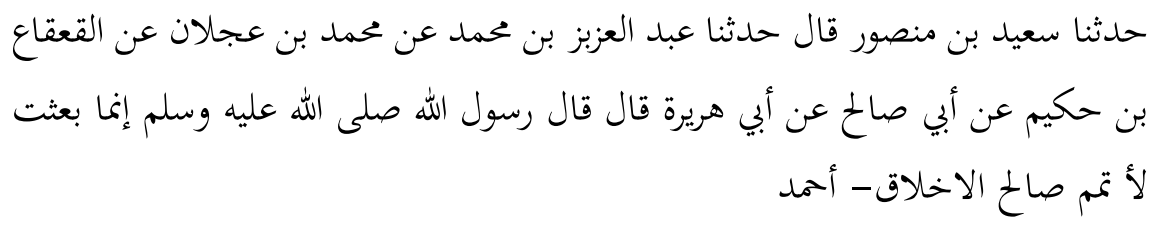

Telah menceritakan kepada kami Said bin Manshur, menceritakan kepada kami Abdullah bin Muhammad dari Muhammad bin Ijlan dari alQa'qa'a bin Hakim dari Abi Shalih dari Abu Hurairah ra berkata, Rasulullah saw bersabda: "Sesungguhnya aku diutus untuk menyempurnakan akhlak". (HR. Ahmad).

\footnotetext{
${ }_{9}^{9}$ Abbuddin Nata, Konsep Pendidikan Ibn Sina (Jakarta: UIN Jakarta Press, 2004), 78.
} 
Versi lain dalam hadits riwayat Bukhari ra seperti berikut; ${ }^{10}$

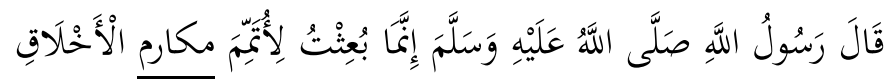

Jika dipahami makna hadits ini nampak jelas bahwa tujuan pendidikan adalah membentuk dan mewujudkan generasi yang berakhlak dan beradab. Karena sejatinya pendidikan adalah proses memanusiakan manusia, artinya melalui pendidikan tersebut manusia (peserta didik) dibina, dibimbing, diarahkan, dididik dan diajarkan ilmu pengetahuan sehingga mereka menjadi orang yang berilmu yang mana bisa membedakan mana yang baik, mana yang buruk, mana yang perintah dan mana yang larangan sehingga terbentuk akhlak dan prilaku yang mulia dalam kehidupan sehari hari.

Analisa penulis di atas dapat diperkuat dengan uraian tentang hubungan akhlak dengan pendidikan, ${ }^{11}$ bahwa pemahaman tentang akhlak membantu merumuskan tujuan pendidikan, yaitu membentuk manusia agar memiliki akhlak mulia atau kepribadian yang utama yang ditandai oleh adanya integritas kepribadian yang utuh. Dengan bantuan akhlak dapat dirumuskan tujuan pendidikan secara keseluruhan mengarah kepada terbentuknya manusia yang baik, ${ }^{12}$ manusia yang berakhlak mulia, 13 manusia yang sempurna, ${ }^{14}$ serta manusia yang berkepribadian Muslim. ${ }^{15}$ Sehingga proses pembentukan akhlak menjadi salah satu tujuan pendidikan sesuai dengan apa yang disabdakan oleh Nabi saw tersebut.

${ }^{10}$ HR. Bukhari dalam Muhammad Jamaluddin Qosim, Mauidhatul Mu'minin Juz 2 (Libanon: Darul Kitab Al-Islami, 2005), 3.

${ }^{11}$ Abudin Nata, Pemikiran Pendidikan Islam dan Barat (Jakarta: PT Raja Grafindo Persada, 2013), 209-200

12 Muhammad al-Nuqaib al-Attas, Aim and Objectivinesnn of islamic Education (Jeddah: King Abdul Aziz University, 1979), 1.

13 Muhammad Athiya al-Abrasyi, Dasar-dasar Pokok Pendidikan Islam, terj. Bustami A.Ghani dan Djohar Bahry (Jakarta: Bulan Bintang, 1974), 15.

${ }_{14}$ Munir Mursi, al-Tarbiyah al-Islamiyah Ushuluha wa Tatawwuruha fi Bilad alArabiyah (Kairo: Alam al-Kutub, 1977), 18.

15 Ahmad D. Marimba, Pengantar Filsafat Pendidikan islam (Bandung: Al-Ma'arif, 1989), 39. Lihat juga Omar Muhammad al-Toumy al-Syaibani, Filsafat Pendidikan Islam (Jakarta: Bulan Bintang, 1979), 519-525. Bandingkan dalam Muhammad Athiyah alAbrasyi, al-Tarbiayah al-Islamiyah wa Falasifatuha (Mesir: al-Halabi, 1969), 225. 
Tujuan pendidikan selain membentuk akhlak dan pribadi yang mulia, juga mengarahkan peserta didik untuk mendapat kebagiaan hidup di dunia dan di akhirat sesuai dengan sabda Nabi saw:

$$
\begin{aligned}
& \text { حدّثنا زهير بن هرب حدّثنا إسماعيل يعنى إبن علية عن عبد العزيز وهو إبن صهيب قال } \\
& \text { سأل قتتاده أناسا أى دعوة كان يدعوبها النبي ص م أكثر؟ قال كَانَ أَكْتَرُ دَعْوَةَ يذْ عُو بهاً } \\
& \text { يَقُول " اللهُمَّ أتِنَا في الدَنْياً حسنَة وفنِ الا خِرَة حسنة وَقِنَا عَذَابَ النّار" رواه مسلم }
\end{aligned}
$$

Telah menceritakan kepada kami Zuhair ibn Harb, menceritakan kepada kami Ismail yakni ibn Ulaiyyat dari Abdul Aziz dan dia adalah ibn Shuhaib, 'Qatadah bertanya kepada Anas, 'Doa apakah yang paling sering di gunakan oleh Rasulullah saw? Anas menjawab, "Kebanyakan doa Nabi saw adalah, "Ya Allah, berilah kami kebaikan di dunia dan kebaikan di akhirat, serta periharalah kami dari siksa neraka". (HR. Muslim) ${ }^{16}$

Adapun tujuan pendidikan selanjutnya adalah untuk mengapai kehidupan dunia dan akhirat. Begitu pentingnya pendidikan bagi manusia (peserta didik), karena pendidikan selain mengajarkan ilmu pengetahuan juga mengembangkan kompetensi yang ada didalam diri peserta didik, sehingga kompetensi (kemampuan/bakat/minat/ ketrampilan) peserta didik dapat dilahirkan. Dengan ilmu dan bakat yang dimilikinya maka ia akan hidup bahagia dan sejahtera di dunia dan di akhirat. Tanpa ilmu dan bakat yang di milki akan menjadikan kehidupannya susah dan menderita.

Sebagai pelengkap, tujuan pendidikan Islam juga mengarahkan peserta didik untuk menjadi orang yang mandiri, artinya tidak bergantung pada orang lain, tidak berpangku tangan pada orang lain dan tidak menyandarkan dirinya pada orang lain, ia berusaha tidak menyusahkan orang lain dengan cara bekerja keras penuh tanggung jawab dan terampil, ini adalah bagian dari tujuan pendidikan Islam, sebagaimana sabda Nabi saw:

${ }^{16}$ Abi al-Husani Muslim Ibn Hajjaj al-Qusyairi al-Naisabury, Shahih Muslim (Beirut: Dar al-Kutub al-'Ilmiyyah, 261 H), 1037.

Tarbawiyah: Jurnal Ilmiah Pendidikan :: Volume 04; Nomor 1, Juni 2020 


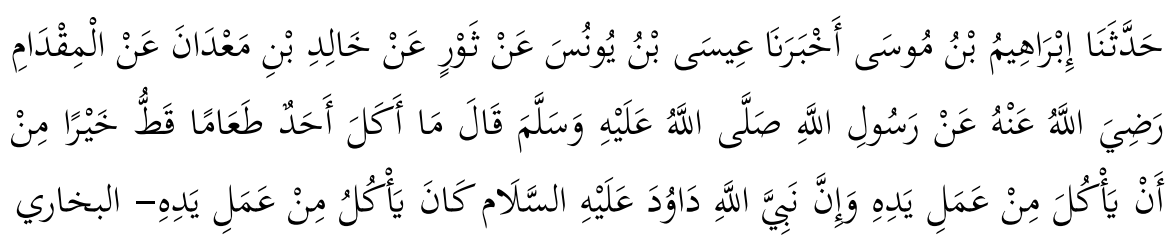

"Di ceritakan Ibrahim bin Musa mengabarkan kepada kami Isa bin Yunus dari Tsurin dari Khalid bin Ma'dan dari Miqdad ra, "dari Nabi SAW bersabda: tidak ada makanan yang di makan seseorang yang lebih baik dari pada hasil usahanya sendiri. Dan sesungguhnya Nabi Daud as, selalu makan dari hasil usahanya sendiri". (HR. Bukhari)

Untuk menjadi orang yang bisa bekerja dengan usahanya sendiri diperlukan sifat mandiri, melalui sifat tersebut seseorang akan terjauhkan dari sifat bergantung pada orang lain. Ia akan berusaha dengan keras untuk melakukan segala sesuatu penuh tanggung jawab. Sehingga akan terbentuk generasi yang kuat dan tanggguh. ${ }^{17}$

\section{Lembaga Pendidikan Islam}

Berkaitan dengan lembaga pendidikan Islam, Imam Bukhari pernah meriwayatkan hadis dari Malik bin al-Huwairits bahwa telah berkata:

$$
\text { وقال مالك بن الحوارث قالنا النبي ص م إرجعو إلى أهليكم فعلموهم. رواه البخاري }
$$

Malik bin al-Huwairits berkata: "Rasulullah saw bersabda: ' Kembalilah kalian kepada keluargamu, kemudian ajarilah mereka." (HR. Bukhari) ${ }^{18}$

Keluarga adalah lembaga pendidikan pertama dalam membentuk kepribadian anak, sehingga peran orang tua sangat penting. Di samping itu, anak adalah titipan dan amanah bagi orang tua sehingga orang tua

17 Sifat mandiri dapat ditanamkan dalam proses pembelajaran melalui pemberian tugas, ekstakulikuler dan kepramukaan, dalam hal ini anak akan mempunyai sikap tanggung jawab atas tugas yang ia emban, dan anak akan mempunyai sikap kreatif atas ekstakulikuler yang ia ikuti serta anak akan mempunyai sikap tangguh dan disiplin atas kegiatan kepramukaan yang ia ikuti. Dengan sikap tangung jawab, kreatif, tangguh dan disiplin inilah yang akan melahirkan anak itu untuk bersikap mandiri, ia bisa hidup sendiri atau berusaha sendiri tanpa menyandarkan diri pada orang lain, karena ia mempunyai skill, dan skill itu dilahirkan dari sikap-sikap tersebut.

18 Bukhari, Shahih Bukhari., 34. 
harus bertanggungjawab secara penuh terhadap perkembangan anaknya, baik mengenai psikis, jasmani, sikap, pergaulan, tingkah laku (akhlak), serta pendidikannya.

Rumah merupakan tempat pendidikan Islam pertama, yang hal itu dibuktikan dengan sejarah pendidikan Islam pada masa Rasulullah saw yang menjadikan rumah arqam bin abil arqam sebagai tempat atau lembaga pendidikan bagi para sahabat beliau, yang kemudian dikenal dengan sebutan 'Dar arqam'. Dalam rumah tersebut dilaksanakan pendidikan bagi para sahabat yang dibina langsung oleh Nabi saw., disitu Nabi saw mengajarkan dasar-dasar ajaran agama Islam, membaca al-Qur'an, dan masalah keislaman lainnya. Para sahabat juga dididik untuk membersihkan akidah dan mensucikan jiwanya, hal tersebut sebagai pendidikan awal bagi mereka. Oleh karenanya, Rasul saw saat itu hanya fokus pada dasar keimanan, tauhid dan akhlak. ${ }^{19}$ Yang mana dalam perkembangan lembaga pendidikan Islam berikutnya pusat pendidikan Islam beralih ke masjid, surau, kuttab, madrasah, hingga berdirinya sekolah dan perguruan tinggi yang terus berkembang sampai serkarang ini. Namun menurut penulis, hal itu tidak mengurangi fungsi keluarga/rumah sebagai lembaga pendidikan pertama dan terpenting bagi anak terlebih pada usia dini.

Sebelum anak itu menerima pendidikan di luar, maka orang tua harus memberikan pendidikan terlebih agama dirumah, yang berkenaan dengan pendidikan tauhid, sopan santun, perkataan yang baik, dan berbuat baik kepada sesama. Ini merupakan pendidikan dasar yang harus ditanamkan kepada anak pada usia dini dalam lingkup pendidikan keluarga, agar anak memiliki pribadi yang baik dan kuat sehingga ketika ia keluar untuk menerima pendidikan di sekolah atau lembaga lain, ia sudah mempunyai dasar dan bekal akan ilmu pengetahuan, dengan begitu ia akan mudah menyerap dan memahami ilmu-ilmu pengetahuan yang lain. ${ }^{20}$

Oleh karena itu, pendidikan keluarga yang ada di rumah merupakan pendidikan pertama bagi anak dan pendidikan yang

19 Muhammad 'Athiyyat al-Abrasi, Al-Tarbiyat al-Islamiyat wa Falasifatuha (Kairo: Dar al-Fikr, t.t), 72. Lihat juga Ali al-Jumbulati, Perbandingan Pendidikan Islam (Jakarta: Rineka Cipta, 1994), 22.

20 Masalah tanggungjawab orang tua dalam mendidik dan menjaga anaknya telah Allah swt ingatkan dalam firman-Nya: "Hai orang-orang yang beriman, peliharalah dirimu dan keluargamu dari api neraka yang bahan bakarnya adalah manusia dan batu.." (QS. At-Tahrim: 6) 
penting guna membekali anak dengan nilai-nilai luhur, pendidikan tersebut tidak akan terwujud manakala orang tua tidak memiliki tanggungjawab yang penuh akan hal itu. Melalui ayat diatas, sepatutnya bagi orang tua untuk menjadikan rumah sebagai tempat untuk mendidik anak disamping untuk berteduh dan istirahat. Dengan begitu, akan tercipta keluarga yang berkualitas baik dari segi spiritual, sosial maupun inteletual, inilah harapan ajaran agama Islam (al-Qur'an dan as-Sunnah) mengenai pendidikan keluarga.

\section{Materi Pembelajaran}

Berkaitan dengan materi pembelajaran, telah menceritakan kepada kami Ismail bin Ibrahim.

$$
\text { صد م حثنا إسماعيل بن إبرهيم أخبرناأبوا خيان التيمي عن أبى زرعة عن أبي هريرة قال كان النبي }
$$

Telah menceritakan kepada kami Ismail bin Ibrahim, memberitakan kepada kami Abu Hayyan al-Tamimi dari Abi Zar'at dari Abu Hurairah ra, ia berkata: 'Pada suatu hari ketika Nabi saw sedang duduk bersama sahabat, tiba-tiba datang seorang laki-laki dan bertanya; 'Apakah Iman itu? Jawab Nabi: "Iman itu adalah percaya kepada Allah swt, para malaikat-Nya, dan pertemuan dengan-Nya, para Rasul-Nya dan percaya pada hari berbangkit dari kubur..." (HR. Bukhari)21

Dalam hal ini Rasul saw memberikan isyarat bagi kita, agar dalam memberikan materi pembelajaran kepada anak didik memuat materi tentang keimanan dan ketauhidan sebagai dasar terhadap pengenalan mereka kepada Allah swt, malaikat, kitab, rasul, hari akhir dan takdir. Materi keimanan sangat penting dan harus diberikan kepada anak didik terlebih pada usia dini, pengenalan Allah swt sebagai Tuhannya pun harus dikenalkan sejak dini. Oleh karenya tidak heran jika kita melihat anak-anak TK atau RA sudah hafal asmaul husna, rukun Iman, dan rukun Islam dengan lantang disertai lagu, ini menurut penulis adalah

${ }^{21}$ Ahmad Ibn Hajr al-Asqalani, Fath al-Bari bi Syarhi Shahih al-Bukhari; Kitab Iman Juz I (Kairo: Dar al-Hadits, 2004), 142. 
langkah yang tepat bagi aqidah mereka, ditambah lagi jika mereka mengaji di TPQ atau TPA sehingga aqidah mereka sejak dini sudah dibina dan dibimbing untuk menjadi manusia yang beriman dan bertaqwa. Pendidikan keimanan adalah sinergi berbagai unsur aktivitas pedagogis yakni pengaitan anak-anak dengan dasar keimanan, pengakrabannya dengan rukun Islam dan pembelajarannya dengan prinsip-prinsip syari'at Islam. ${ }^{22}$

Dengan mengutip firman Allah swt mengenai kisah Lukmanul Hakim yang berwasiat terhadap anak nya, "dan (ingatlah) ketika Luqman berkata kepada anaknya, di waktu ia memberi pelajaran kepadanya: "Hai anakku, janganlah kamu mempersekutukan Allah, Sesungguhnya mempersekutukan (Allah) adalah benar-benar kezaliman yang besar". (QS. Luqman: 13)

Betapa Allah swt mengabadikan wasiat Luqman al-Hakim terhadap anaknya dalam firman-Nya mengenai keimanan dan ketauhidan tersebut, agar selalu mensucikan-Nya dari segala sesuatu dan melarang kita untuk tidak menyekutukanNya dengan siapun itu. Dan kemudian Allah swt menegaskan lagi dalam surah al-Ikhlas ayat 14. Oleh karena, kita sebagai pendidik harus memberikan nilai-nilai keimanan kepada anak didik kita, supaya mereka mempunyai aqidah yang kuat sehingga tidak mudah terbawa oleh arus dan bujukan orangorang atau aliran yang tidak sejalan dengan aqidah Islam.

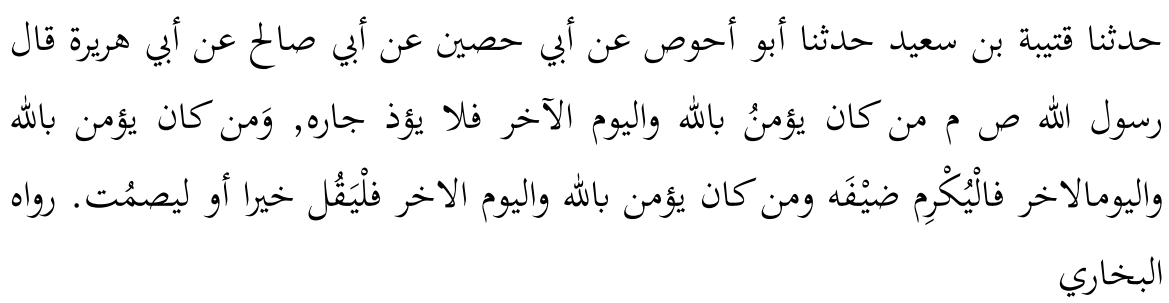

Telah menceritakan kepada kami Qutaibah ibn Sa'id, menceritakan kepada kami Abu Ahwas dari Abi Hashin, dari Abu Shalih dari Abu Hurairah ra, ia berkata: 'Rasulullah saw bersabda: "Siapa yang beriman kepada Allah swt dan hari akhir, maka janganlah menyakiti tetangganya, dan siapa yang beriman kepada Allah swt dan hari Akhir maka

${ }^{22}$ Hannan Athiyyat al-Thuri, Mendidik Anak Perempuan di Masa Kanak-Kanak (Jakarta: Amzah, 2007), 1.

Tarbawiyah: Jurnal Ilmiah Pendidikan :: Volume 04; Nomor 1, Juni 2020 
hendaklah memuliakan tamunya, siapa yang beriman kepada Allah swt dan hari Akhir maka hendaklah ia berbicara yang baik atau lebih baik diam." (HR. Bukhari) ${ }^{23}$

Selain materi tentang keimanan, materi tentang sosial juga perlu dan harus diberikan kepada anak didik, seperti berbuat baik kepada sesama, sopan santun, saling tolong menolong, saling mengasihi, menyayangi, menghormati, menghargai dan berkata baik kepada siapapun, baik kepada orang tua, guru, teman, orang lain dan sebagainya.

Pendidikan sosial adalah proses yang di mana menjadi sarana seseorang untuk mempelajari cara-cara masyarakat maupun kelompok sosial sehingga dia dapat hidup dalam masyarakat. Atau dengan kata lain, pendidikan sosial adalah proses pembentukan perilaku sosial dalam ruang individu dan memasukkan kebudayaan masyarakat dalam bangunan personalitas. ${ }^{24}$ Ini kiranya, yang perlu kita tanamkan kepada anak didik kita, agar mereka menjadi anak didik yang mempunyai jiwa sosial yang tinggi didukung dengan sikap yang mulia dan kecerdasan yang mumpuni, sehingga pendidikan Islam berhasil mewujudkan generasi yang ulul albab (cerdas secara spiritual, sosial, dan sikap).

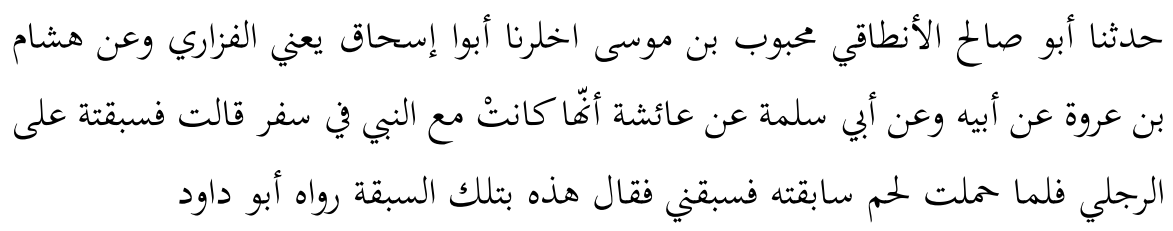

Telah menceritakan kepada kami Abu Shalih al-Anthaqi Mahbub bin Musa, memberitakan kepada kami Abu Ishaq yakni al-Fazari dari Hisyam ibn Urwat dari ayahnya dari Abi Salamah dari Aisyah ra, 'Bahwasannya dia pernah bersama Nabi saw dalam perjalanan, aku berpacu lari dengan beliau dan aku berhasil memenangkannya. Kemudian ketika aku sudah gemuk aku mengajak beliau berpacu, dan beliau menyalipku, sambil berkata; "Ini untuk perlombaan yang dulu" (HR. Abu Dawud) ${ }^{25}$

${ }^{23}$ Bukhari, Shahih Bukhari., 1108.

${ }^{24}$ Hannan Athiyyat, Mendidik Anak., 235-236.

${ }^{25}$ Abi Dawud Sulaiman ibn al-Asy'asy al-Sajastani, Sunan Abi Dawud (Beirut: Dar al-Kutub al-Ilmiyyat, 2004), 411-412. 
Membentuk anak didik menjadi anak yang cerdas secara spiritual dan sosial tidak cukup, jika tidak diimbangi dengan materi tentang jasmani/olah raga (kesehatan dan kebugaran), Islam menghendaki umatnya untuk menjadi Muslim yang kuat dan sehat, tentu melalui olah raga sebagaimana yang di contohkan Nabi saw, yakni mulai dari olah raga lari, memanah, berkuda dan berenang. Yang dalam hal ini penulis hanya membahas salah satu olah raga yang dianjurkan dan contohkan Nabi saw yakni mengenai olah raga lari.

Pendidikan jasmani adalah bentuk aktivitas yang dilakukan oleh seseorang dengan gerakan tubuh yang teratur dengan tujuan meningkatkan berbagai kemampuan tubuh yang bermacam-macam dan menambah kecekatan gerakan. ${ }^{26}$ Olah raga lari memang merupakan olah raga yang simple dan tidak membutuhkan banyak biaya dan alat, sehingga mudah untuk dilakukan oleh orang, baik dari anak-anak, remaja, dewasa, orang tua maupun orang tua, dan sering dijadikan sebagai perlombaan lari. Disatu sisi, sebagai sunnah Nabi saw, disisi lain memang mengandung banyak manfaat bagi kesehatan dan kebugaran tubuh terlebih bagi otot.

\section{Metode Pembelajaran}

$$
\begin{aligned}
& \text { حدّثنا إبراهيم بن حمزة قال حدّثني ابن أبي حازم والدراوردي عن يزيد عن محمد بن إبرهيم }
\end{aligned}
$$

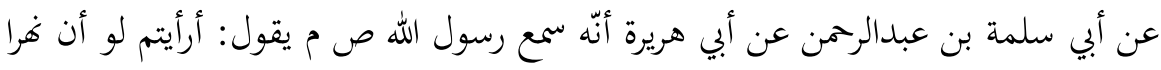

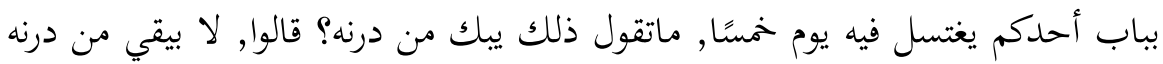

$$
\begin{aligned}
& \text { شيئا. قال فذالك مثل الصلوت الخمس يمحو الله به الخطايا. رواه البخاري }
\end{aligned}
$$

Telah menceritakan kepada kami Ibrahim bin Hamzah, ia berkata menceritakan kepada kami ibn Abu Hazm dari al-Darawardi, dari Yazid dari Muhammad ibn Ibrahim, dari Abu Salamah ibn Abdurrahman, dari Abu Hurairah ra bahwa ia mendengar Rasulullah saw bersabda; 'Bagaimana pendapat kalian seandainya ada sungai di depan pintu salah seorang diantara kalian. Ia mandi di sana lima kali sehari, bagaimana pendapat kalian? Apakah masih tersisa kotorannya?, Mereka menjawab: Tidak akan tersisa kotorannya sedikitpun. Beliau bersabda: "Begitulah

${ }^{26}$ Hannan Athiyyat, Mendidik Anak., 53.

Tarbawiyah: Jurnal Ilmiah Pendidikan :: Volume 04; Nomor 1, Juni 2020 
perumpamaan salat lima waktu, dengannya Allah swt menghapus dosadosa." (HR. Bukhari) ${ }^{27}$

Dalam proses pembelajaran guru membutuhkan yang namanya metode, agar materi bisa sampai kepada anak didik dengan mudah. Dengan metode anak didik dapat memahami materi yang disampaikan guru sehingga proses belajar akan berjalan efektif dan efisien. Hal ini dicontohkan langsung oleh Nabi saw.,dalam hadits diatas, ketika Nabi memberikan materi kepada para sahabat, beliau memakai metode tanya jawa yang secara langsung melibatkan peserta didik (para sahabat), sehingga para sahabat mengetahui dan memahami materi yang disampaikan Nabi saw tersebut. Melalui metode ini, anak didik akan dapat memahami dan mempunyai gambaran dalam benak dan fikirannya sehingga ia akan mudah menerima materi tersebut.

Dalam mengajar memang harus menggunakan banyak metode, agar materi pelajaran dapat sampai kepada peserta didik dengan baik dan mendalam. Salah satunya melalui metode tanya jawab sebagaimana yang dicontohkan Nabi saw dalam sabdanya. Sebagai penguat dari pendapatnya Zakiah Darajat, bahwa metode tanya jawab merupakan cara penyajian dalam bentuk pertanyaan yang harus dijawab terutama dari guru ke peserta didik, tetapi juga bisa dari peserta didik ke guru, hal ini dimaksudkan untuk merangsang otak mereka agar berpikir dan membimbing mereka dalam mencapai kebenaran. ${ }^{28}$

$$
\begin{aligned}
& \text { حدثنا ادم قال أخبرنا شعبة أخبرين الحهم عن ذر عن سعيد بن عبد الرمن بن أبزى عن }
\end{aligned}
$$

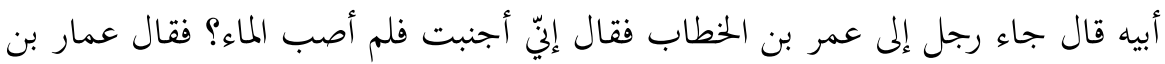

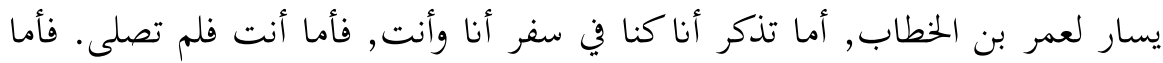

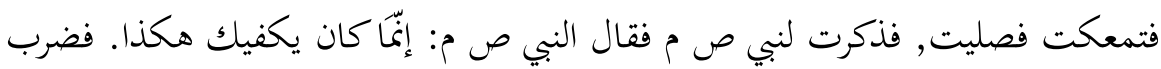

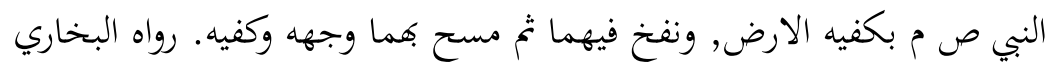

27 Bukhari, Shahih Bukhari, 111.

28 Pupuh Fathurrahman dan M. Sobry Sutikno, Strategi Belajar Mengajar (Bandung: PT Refika Aditama, 2011) , 62 
Menceritakan kepada kami Adam, ia berkata, memberitahukan kepada kami Syu'bah, memberitahukan kepadaku Hakam, dari Jar, dari Sa'id ibn Abdurrahman ibn Abza', dari ayahnya, ia berkata, Telah datang Ammar ibn Yasir berkata kepada Umar bin Khattab, 'Tidaklah anda ingat seseorang yang datang kepadamu, lalu ia berkata; 'Sesungguhnya aku sedang junub dan aku tidak menemukan air? Maka berkata Ammar bin Yassir kepada Umar bin Khattab ra, 'Ketika saya dan anda dalam sebuah perjalanan. Adapun anda belum shalat, sedangkan saya bergulunggulung ditanah kemudian saya shalat, saya pun menceritaknnya kepada Rasul saw, kemudian beliau bersabda; "Sebenarnya anda cukup begini, Rasul saw memukulkan kedua telapak tangannya ke tanah dan meniupnya kemudian mengusapkan keduanya pada wajah dan tangan beliau." (HR. Bukhari) ${ }^{29}$

Dalam hal ini, Nabi telah mencontohkan metode demonstrasi yakni mempraktikkan tayammum sebagai penganti wudhu dan mandi besar. Jika materi apalagi materi tentang praktik (shalat, wudhu, zakat, haji, qurban, tayammum, mandi, dan lain sebagainya) hanya disampaikan dalam bentuk ceramah maka anak didik akan sulit memahami dan mengerti akan materi tersebut, sehingga mereka tidak punya gambaran mengenai tata cara tentang materi tersebut dengan benar. Oleh karena itu, untuk mengatasinya di butuhkan matode yang pas, yakni metide demontrasi sebagaimana yang dicontohkan langsung oleh Nabi saw. 30

\section{Pendidik}

حدّثنا محمد بن عبد الأعلى الصنعاني أخبرنا سلمة بن رجاء أخبرنا الولييد بن جميل أخبرنا

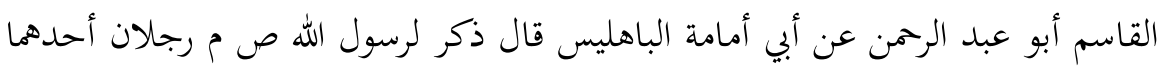

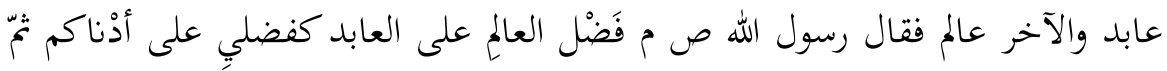

29 Bukhari, Shahih Bukhari., 78.

30 Metode demonstrasi adalah metode mengajar dengan cara mempragakan barang, kejadian, aturan, tata cara, dan urutan dalam melakukan sesuatu pekerjaan, baik secara langsung maupun melalui penggunaan media pengajaran yang relevan dengan pokok bahasan yang sedang disajikan. Metode ini bertujuan untuk memperjelas pengertian konsep dan memperlihatkan cara melakukan sesuatu atau proses terjadinya sesuatu. Baca Pupuh Fathurrahman, Strategi., 62. 


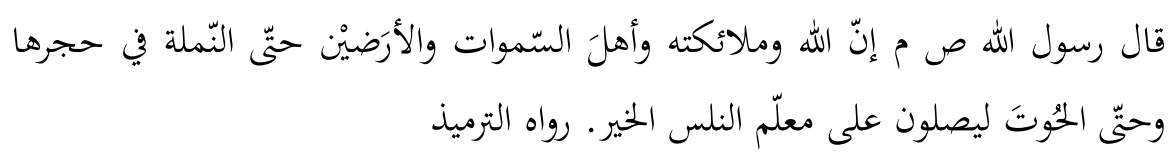

"Telah menceritakan kepada kami Muhammad ibn 'Abdul A'la alShan'ani, memberitahukan kepada kami Salamat ibn Raja', memberitahukan kepada kami Walid bin Jamil, memberitahukan kepada kami Qasim ibn 'Abdurrahman, dari Abu Umamat al-Bahili, berkata: "Disebutkan bagi Rasulullah saw, ada dua orang laki-laki, satu orang ahli ibadah dan satu lagi ahli ilmu. Maka Rasulullah saw berkata: "Keutamaan seorang ahli ilmu atas ahli ibadah seperti keutamaan antara saya dengan yang paling rendah di antara kamu". Kemudian berkata Rasulullah saw. 'Sesungguhnya Allah, malaikat-Nya, penduduk langit dan bumi, sampai semut yang berada di batu dan ikan, mereka bersalawat kepada seorang pendidik yang mengajarkan kebaikan (ilmu)". (HR. At-Tirmidzi) ${ }^{31}$

Hadits tersebut di atas membicarakan tentang keutamaan yang dimiliki seorang pendidik (mu'allim). Di antara keutamaannya ialah orang yang berilmu (mu'allim) memiliki keutamaan di atas orang ahli ibadah (abid) seperti keutamaan Rasulullah atas orang-orang yang paling rendah di antara sekalian manusia, Allah dan malaikat-malaikatNya serta penduduk langit dan bumi sampai semut dan ikan pun ikut bersalawat atau mendoakan meraka orang berilmu yang mengajarkan kebaikan dengan ilmunya. ${ }^{32}$

Makna Mu'allim dalam pembahasan ini adalah seorang pendidik (guru) yang senantiasa mencurahkan dan memberikan ilmu kepada murid-muridnya. Dengan tujuan agar mereka menjadi generasi yang baik dan cakap. Seorang mu'allim dalam hadits ini ditempatkan diposisi yang sangat mulia, karena keilmuan dan kealimannya dibanding seorang yang ahli ibadah tanpa ilmu. Mencurahkan dan memberikan ilmu serta membimbing anak didiknya merupakan tugas dan tanggung jawab seorang pendidik (guru). Guru sebagai orangtua kedua memilki tanggung jawab pendidikan yang baik kepada peserta didik (anak

\footnotetext{
${ }^{31}$ Abi Isa Muhammad Ibn Isa Ibn Surah al-Tirmidzi, Sunan at-Tirmidzi (t.tp: Dar al-Fikr, 1983), 632.

${ }^{32}$ Samsul Nizar dan Zainal Efendi Hasibuan, Hadis Tarbawi., 120.
} 
didik)nya. ${ }^{33}$ Yang hal itu harus dijalankan dan dilaksanakan dengan sebaik-baiknya sehingga nantinya mengahasilkan lulusan yang berkompeten.

Guru membawa amanah Ilahiah untuk mencerdaskan kehidupan umat manusia dan mengarahkannya untuk senantiasa taat beribadah kepada Allah dan berakhalak mulia. Oleh karena tanggung jawabnya, guru dituntut untuk memiliki berbagai kompetensi, yaitu; ${ }^{34}$ (a) Kompetensi profesional merupakan kemampuan penguasaan materi pelajaran; (b) Kompetensi pedagogik merupakan kemampuan guru dalam mengelola pembelajaran peserta didik; (c) Kompetensi sosial merupakan kemampuan pendidik sebagai bagian dari masyarakat; dan (d) Kompetensi kepribadian adalah kemampuan kepribadian yang mantap, stabil, dewasa, arif, wibawa dan berakhlak mulia.

Dengan kompetensi-kompetensi tersebut, akan menjadikan guru sebagai pribadi yang tanggung jawab dan berkualitas, sehingga dalam mengajar, membimbing dan mengarahkan peserta didik menjadi manusia yang berilmu dan berakhlak akan dapat terlaksana dengan baik dan sukses. Kemudian Nabi saw dalam sabda yang lain menjelaskan bagaimana pentingnya peran seorang pendidik dalam memajukan dan menghidupkan ilmu-ilmu Allah swt dimuka bumi ini agar bisa mencetak generasi berilmu dan berakhlak yang berguna bagi kehidupan masyarakat, agama dan bangsa.

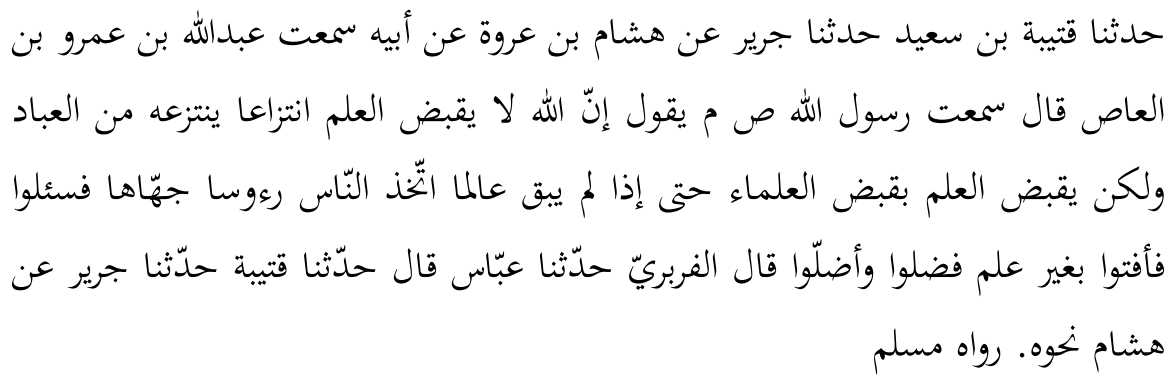

"Telah menceritakan kepada kami Qutaibah bin Sa'id, menceritakan kepada kami Jarir, dari Hisyam bin 'Urwah, dari Ayahnya; Aku mendengar 'Abdullah bin Amru bin 'Ash ra. Ia berkata: Aku mendengar Rasulullah saw bersabda: "Sesungguhnya Allah tidak mengambil ilmu

${ }^{33}$ Novan Ardi dan Barnawi, Ilmu Pendidikan Islam (Jogyakarta: Ar-Ruzz Media, 2012), 97.

${ }^{34}$ Novan dan Barnawi, Ilmu Pendidikan., 102. 
dengan cara mencabutnya begitu saja dari manusia, akan tetapi Allah akan mengambil ilmu dengan cara mencabut (nyawa) para ulama', sehingga ketika Allah meninggalkan seorang ulama' pun, manusia akan mengangkat pemimpin-pemimpin yang bodoh yang apabila ditanya mereka akan memberikan fatwa tanpa didasarkan pada ilmu pengetahuan lalu mereka pun sesat serta menyesatkan". (HR. Muslim) ${ }^{35}$

Berdasarkan hadits ini, terlihat peranan mu'allim sangat penting dalam upaya pencerdasan umat. Dalam hadits ini dijelaskan, Allah tidak mencabut ilmu secara langsung dari manusia, akan tetapi Allah mencabutnya dengan hilangnya atau meninggalnya para ulama', sehingga apabila ulama telah tidak ada, orang-orang akan mengangkat pemimpin yang bodoh sebagai tempat bertanya. Pemimpin yang bodoh tersebut, menjawab pertanyaan atau berfatwa dengan fatwa yang sesat lagi menyesatkan. Oleh karenanya, umat semakin sesat, jauh dari cahaya kebenaran. Hadits ini mengambarkan pentingnya seorang mu'allim di tengah-tengah umat agar dasar agama tetap dapat dijalankan dan dipertahankan. Ketiadaan mu'allim di tengah-tengah umat, akan dapat merusak pola pikir manusia, karena akan jauh dari ketetapan Illahi.

\section{Peserta Didik}

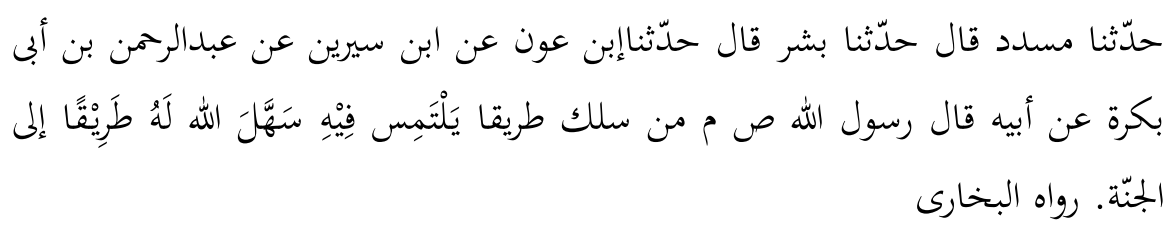

"Telah menceritakan kepada kami Musaddad, berkata menceritakan kepada kami Bisyr, ia berkata, menceritakan kepada kami Ibn 'Aub, dari Ibn Sirin, dari Abdurrahman ibn Abu Bakrah dari ayahnya, Rasulullah saw bersabda; 'Barangsiapa yang berusaha mencari ilmu, maka Allah akan memudahkan baginya jalan menuju surga". (HR. Bukhari) ${ }^{36}$

35 Abi al-Husaini Muslim, Shahih Muslim., 1030.

${ }^{36}$ Bukhari, Shahih Bukhari., 30. 
Hadits ini dapat dijadikan motivasi dan semangat bagi para pencari ilmu (peserta didik), bahwasannya seseorang yang berusaha menempuh jalan untuk niat mencari ilmu dan ridha Allah tentunya, maka Allah sendiri yang akan memudahkan baginya jalan menuju surga, dapat kita katakan bahwa mencari ilmu karena Allah sama dengan berjalan menuju surga-Nya. Ini menandakan bahwa Allah swt sangat mengapresiasi para penuntut ilmu (peserta didik/santri /mahasiswa dan lain sebagainya) dengan surga sebagai jaminan dan imbalan bagi mereka para penuntut ilmu.

Oleh karenanya, tidak ada alasan bagi kita untuk berhenti mencari ilmu, kita harus senantiasa berusaha mencari ilmu dimanapun, kapanpun dan dengan cara apapun. Perlu diingat bahwa mencari ilmu disini tidak hanya di pendidikan formal saja, namun bermakna luas, yakni Allah membebaskan kita mencari ilmu dimana saja dan dengan cara apa saja. Seperti, di pondok pesantren, masjid, majelis-majelis ta'lim, privat, mengkaji buku atau kitab, membaca dan memahami kitab/buku, dan lain sebagainya. Intinya bertujuan untuk menambah wawasan keilmuan. Masalah umur tidak menjadi alasan untuk berhenti mencari ilmu karena ilmu tidak terbatas/dibatasi oleh waktu dan tempat. Selagi umur masi dikandung badan maka kita masih diwajibkan untuk menuntut dan belajar ilmu pengetahuan, dengan berbagai cara seperti yang sudah penulis sebutkan diatas.

Namun di samping itu, ada hal-hal yang perlu diketahui dan dipahami bagi para pencari ilmu, yakni terkait dengan adab seorang pencari ilmu yang penulis rasa mulai ditinggalkan dan diacuhkan oleh para pencari ilmu, akibatnya mereka tidak bisa mengaplikasikan (mengamalkan) ilmu yang diperoleh dengan baik. Adab dalam mencari ilmu sangat perlu untuk di laksanakan mengingat ilmu itu mulia sebagai cahaya yang harus diterima dan diperoleh dengan cara-cara mulia juga agar ilmu itu memberikan manfaat dan barakah bagi si penerima ilmu tersebut yakni peserta didik.

Segala hal yang harus dipenuhi oleh peserta didik dalam proses belajar mengajar sebagaimana yang diuraikan oleh Hujjatul Islam alImam Abu Hamid al-Ghazali dalam kitabanya Ayyuhal walad yang penulis kutib dari M. Haitami Salim dalam bukunya, ${ }^{37}$ sebagai berikut; (1) Seorang pencari ilmu hendaklah menjauhkan diri dari perbuatan

37 M. Haitami Salim dan Syamsul Kurniawan, Studi Ilmu Pendidikan Islam (Jogyakarta: ar-Ruzz, 2012), 178.

Tarbawiyah: Jurnal Ilmiah Pendidikan :: Volume 04; Nomor 1, Juni 2020 
keji; (2) Seorang peserta didik hendaknya senantiasa mendekatkan diri kepada Allah swt; (3) Seorang peserta didik hendaknya memusatkan perhatiannya atau konsentrasinya terhadap ilmu yang sedang dikaji/dipelajarinya; (4) Seorang peserta didik hendaknya tidak menyombongkan diri dengan ilmunya; (5) Hendaklah setiap peserta didik tidak melibatkan diri dalam perdebatan atau diskusi tentang segala ilmu pengetahuan; (6) Hendaklah peserta didik tidak meninggalkan suatu mata pelajaran dari ilmu pengetahuan yang terpuji; dan (7) Seorang peserta didik hendaknya tidak memasukkan suatu bidang ilmu pengetahuan dengan serentak.

Jika tata cara atau adab tersebut dilakukan dengan baik, maka peserta didik akan memperoleh ilmu yang manfaat dan barakah dunia akhirat yang akan membawanya kepada kehidupan yang mulia dan diridha Allah swt.

\section{Pendidikan Bagi Wanita}

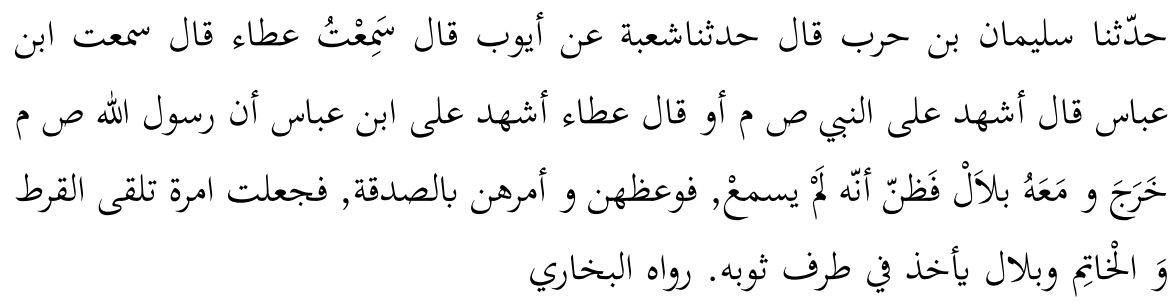

Telah menceritkan kepada kami Sulaiman ibn Harb, ia berkata, telah menceritakan kepada kami Syu'bah, dari Ayyub, ia berkata: "Aku mendengar Atha' berkata, Aku Ibnu Abbas menyaksikan bahwa Rasulullah saw keluar bersama Bilal, maka Rasul saw mengira Bilal tidak mendengarkan beliau, lalu Rasulullah saw memberikan pengajaran kepada para perempuan, dan memerintahkan mereka untuk bersedekah, para wanita itupun melepas anting-anting dan cincin mereka, dan Bilal datang mengambil sedekah tersebut dan memasukkannya ke dalam surbannya". (HR. Bukhari) ${ }^{38}$

${ }^{38}$ Bukhari, Shahih Bukhari, 42. 
Sementara itu, dalam hadis yang lain juga dikisahkan bahwa;

$$
\begin{aligned}
& \text { وقال مجاهدو لايتعلم العلم مستحي ولا مستكبر, وقالت عائشة, نعم النّساء نساء الانصار , }
\end{aligned}
$$

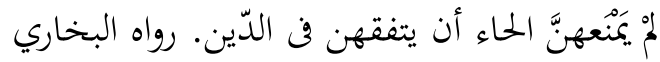

Berkata Mujahid, "Pemalu dan orang sombong tidak akan dapat mempelajari pengetahuan agama". Aisyah ra berkata: "Sebaik-baik kaum wanita adalah kaum wanita Anshar. Mereka tidak dihalanghalangi rasa malu untuk mempelajari pengetahuan yang mendalam tentang agama". (HR. Bukhari) ${ }^{39}$

Maksud hadits ini adalah bahwa wanita tidak diharamkan atau dilarang untuk menuntut ilmu. Mereka diberi hak untuk menuntut ilmu, mengenyam pendidikan sampai tingkat tinggi. Ini artinya wanita mempunyai hak yang setara dengan laki-laki dalam hal mengenyam pendidikan timggi (mencari ilmu), dan wanita yang memperdalam ilmunya (pendidikannya) tergolong wanita yang mulia dan sebaik-baik wanita. Seperti apa yang disampaikan oleh siti Aisyah ra. Ini menegaskan bahwa Islam tidak membedakan (diskriminasi) terhadap kaum wanita dalam hal pendidikan. Bahkan Islam melalui Rasulullah menganjurkan dan mengharuskan kaum Islam baik laki-laki maupun perempuan untuk menjadi orang yang berkualitas salah satunya dengan memperdalam ilmu (pendidikan). Sehingga akan terlahir generasi-generasi muslim dan muslimah yang berkualitas dan beradab.

Dan juga di Indonesia, antara laki-laki dan perempuan sama, yakni sama-sama mempunyai hak untuk belajar, mencari ilmu dan memperoleh ilmu/pendidikan sampai ke jenjang yang lebih tinggi. Ini artinya, pemerintah Indonesia disamping mengamalkan hadist Nabi saw di atas, juga ingin warga negaranya menjadi warga negara yang cerdas dan berprestasi, sehingga dapat memajukan bangsa Indonesia dan dapat bersaing dengan bangsa lain. Serta kehidupan akan lebih baik, makmur dan sejahtera.

${ }^{39}$ Ibid., 42.

Tarbawiyah: Jurnal Ilmiah Pendidikan :: Volume 04; Nomor 1, Juni 2020 


\section{Evaluasi Pembelajaran}

$$
\begin{aligned}
& \text { حدثنا محمدبن عبد الله بن نمير حدّثنا أبي حدّثنا عبدالله عن نافع عن ابن عمر قال عرضني }
\end{aligned}
$$

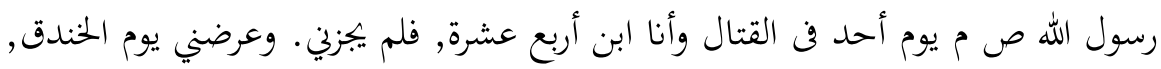

$$
\begin{aligned}
& \text { وأنا بن خمس عشرة سنة, فأجزائ. رواه البخاري }
\end{aligned}
$$

"Telah menceritakan kepada kami Muhammad ibn Abdullah ibn Numair, menceritakan kepada kami ayahku, menceritakan kepada kami Abdullah, dari Nafi', dari Ibnu Umar ra berkata: "Rasulullah saw menguji kemampuan ku berperang pada hari perang Uhud, ketika aku berusia empat belas tahun, lalu beliau tidak mengizinkanku. Dan beliau mengujiku kembali pada hari perang Khandaq ketika aku berusia lima belas tahun, lalu beliau mengizinkan aku". (HR. Muslim). ${ }^{40}$

Jika dilihat dari teori taksonomi Benjamin S. Blomm maka jelaslah bahwa psychological doamins yang dijadikan sasaran evaluasi Nabi saw sebagai pelaksana perintah Tuhan (Allah swt) sesuai wahyu yang diturunkan kepada beliau yang lebih menitik beratkan pada kemampuan dan kesediaan manusia mengamalkan ajaran-Nya, di mana faktor psikomotorik menjadi tenaga pengeraknya. Disamping itu, faktor kognitif (pengetahuan/kemauan) juga dijadikan sasarannya. ${ }^{41}$ Artinya, bahwa Nabi saw sangat memperhatikan kemampuan dan kesediaan seseorang dalam melakukan sebuah tugas/ tangggung jawab dan perintah. Tidak melakukan pembebanan dan paksaan terhadap seseorang. Dengan kemampuan dalam menjalankan tugas, maka bisa dilihat seberapa mampu ia melaksanakan tugas tersebut, inilah yang disebut dengan evaluasi (penilaian/pengujian) yang dilakukan oleh Nabi saw untuk mengetahui tingkat kemampuan atau komptensi seseorang dalam melaksanakan tugas.

Jika kita tarik dalam dunia pendidikan, bahwa seorang guru jika ingin mengetahui tingkat kemampuan dan kemajuan belajar anak didiknya, maka diperlukan evaluasi dengan cara melakukan pengujian, tes dan pemberian pertanyaan-pertanyaan kepada peserta didik terkait

40 Muslim, Shahih Muslim., 748.

41 M. Zainal Arifin, Evaluasi Pembelajaran Prinsip, Teknik dan Prosedur (Bandung: PT Remaja Rosdakarya, 2010), 166. 
materi pelajaran yang diberikan, sehingga nanti seorang guru akan mengetahui tingkat kemampuan dan pemahaman peserta didiknya, yang selanjutnya dapat dilakukan tindak lanjut untuk memperbaiki dan mengembangkan lagi kemampuan dan pemahaman mereka.

Dan jika kita lihat, makna hadits tersebut bisa kita jadikan sebuah pijakan dalam proses kenaikan kelas. Artinya, jika peserta didik kemampuannya dalam menguasai materi (mata pelajaran) kurang menguasai, maka seorang guru sebaiknya tidak menaikkannya ke tingkat yang lebih tinggi. Atau dengan cara melakukan pendalamanpendalaman agar ia bisa segera menguasai dan memahami materi pelajaran tersebut. Hal itu yang dicontohkan Nabi saw dalam hadits tersebut ketika melatih Ibnu Umar (Abdullah bin Umar) yang waktu itu masi berusia 14 untuk ikut perang, namun Nabi setelah mengujinya maka kemampuannya belum secara penuh sehingga ia dilarang untuk ikut perang, namun ketika berusia 15 tahun ia di uji lagi oleh Nabi saw dan ternyata kemampuannya sudah mempuni sehingga ia diperkenankan untuk ikut perang. Sama juga dengan pendidikan di Pondok Pesantren, santri dapat naik ketingkat yang lebih tinggi atau santri boleh berganti kitab, manakala ia lulus tes ujian terlebih dahulu. Jika ia dapat menguasai kitab tersebut maka ia diperkankan untuk naik ke kitab selanjutnya. Namun jika belum menguasai kitab tersebut, maka ia perlu mendalami dan memahaminya lagi.

\section{Kesimpulan}

Dengan demikian konsep pendidikan agama Islam dalam tinjauan hadits-hadits pendidikan (tarbawi) dapat disimpulkan sebagai berikut: Pertama, kedudukan hadits dalam pendidikan agama Islam menjadi sebuah dasar dan landasan bagi konsep, kerangka dan desain pendidikan agama Islam. Kedua, konsep pendidikan agama Islam dalam tinjauan hadits-hadits pendidikan meliputi: dasar pendidikan, kewajiban belajar, tujuan pendidikan, lembaga pendidikan, materi pembelajaran (pendidikan),metode pembelajaran, pendidik (guru), peserta didik (murid), pendidikan wanita dan evaluasi pembelajaran. Kesepuluh inilah yang menjadi kerangka dalam membagun pendidikan agama Islam yang sesuai dengan hadits Rasulullah saw, sehingga pendidikan yang ditawarkan kepada masyarakat tidak jauh berbeda dengan pendidikan masa Rasulullah saw tentu menyesuaikan dengan perkembangan zaman, namun tidak melupakan esensi dasarnya.[] 


\section{Daftar Pustaka}

Abdullah, Abdurrahman Saleh. Teori-teori Pendidikan Berdasarkan alQur'an, terj. H.M. Arifin dari judul asli, Educational Theory: Qur'anic Outbook, Jakarta: Rineka Cipta, 2005.

Aghnides, NP. Muhammadan Theorities of Finance: With an Introduction to Muhammad Law and a Bibliography, New York: AMS Press, 1969.

Al-Abrasyi, Muhammad 'Athiyyat. Al-Tarbiyat al-Islamiyat wa Falasifatuha, Kairo: Dar al-Fikr, t.t.

Al-Abrasyi, Muhammad Athiya. Dasar-dasar Pokok Pendidikan Islam, terj. Bustami A.Ghani dan Djohar Bahry, Jakarta: Bulan Bintang, 1974.

Al-Abrasyi, Muhammad Athiyah. al-Tarbiayah al-Islamiyah wa Falasifatuha, Mesir: al-Halabi, 1969.

Al-Asqalani, Ahmad Ibn Hajr. Fath al-Bari bi Syarhi Shahih al-Bukhari; Kitab Iman Juz I, Kairo: Dar al-Hadits, 2004.

Al-Attas, Muhammad al-Nuqaib. Aim and Objectivinesnn of islamic Education, Jeddah: King Abdul Aziz University, 1979.

Al-Bukhari, Abi Muhammad ibn Ismail ibn Ibrahim ibn al-Mughirah ibn Bardzabat, Shahih al-Bukhari, ttp: Dar Ibn Katsir, 1987.

Al-Jumbulati, Ali. Perbandingan Pendidikan Islam, Jakarta: Rineka Cipta, 1994.

Al-Sajastani, Abi Dawud Sulaiman ibn al-Asy'asy. Sunan Abi Dawud, Beirut: Dar al-Kutub al-Ilmiyyat, 2004.

Al-Syaibani, Omar Muhammad al-Toumy. Filsafat Pendidikan Islam, Jakarta: Bulan Bintang, 1979.

Al-Thuri, Hannan Athiyyat. Mendidik Anak Perempuan di Masa KanakKanak, Jakarta: Amzah, 2007.

Al-Tirmidzi, Abi Isa Muhammad Ibn Isa Ibn Surah. Sunan at-Tirmidzi. tt.p: Dar al-Fikr, 1983.

Alawi, Ziauddin. Pendidikan Islam pada Abad Pertengahan, terj. Abuddin Nata dari judul asli, Islamic Education in Middle Age, Bandung: Angkasa, 2002.

An-Naisabury, Abi al-Husani Muslim Ibn Hajjaj al-Qusyairiy. Shahih Muslim, Beirut: Dar al-Kutub al-'Ilmiyyah, $261 \mathrm{H}$.

Ardi, Ardi dan Barnawi. Ilmu Pendidikan Islam, Jogyakarta: Ar-Ruzz Media, 2012. 
Arifin, M. Zainal. Evaluasi Pembelajaran Prinsip, Teknik dan Prosedur. Bandung: PT Remaja Rosdakrya, 2010.

Bek, Sayyid Ahmad al-Hasyimbi. Mukhtar al-Ahadits al-Nabawiy, Mesir:

Mathba'ah Hijazy, 1948.

Daradjat, Zakiah. Metodik Khsusus Pengajaran Agama Islam, Jakarta: Bumi Aksara, 2001.

Ilmu Pendidikan Islam, Jakarta: Bumi Aksara, 1996.

Fathurrahman, Pupuh dan M. Sobry Sutikno. Strategi Belajar Mengajar,

Bandung: PT Refika Aditama, 2011.

Langgulung, Hasan. Beberapa Pemikiran tentang Pendidikan Islam, Bandung: al-Ma'arif, 1980.

Mujib, Abdul dan Yusuf Mudzakkir. Ilmu Pendidikan Islam, Jakarta: Prenada Media, 2006.

Marimba, Ahmad D. Pengantar Filsafat Pendidikan Islam, Bandung: AlMa'arif, 1989.

Mursi, Munir. al-Tarbiyah al-Islamiyah Ushuluha wa Tatawwuruha fi Bilad al-Arabiyah, Kairo: Alam al-Kutub, 1977.

Nata, Abbuddin. Konsep Pendidikan Ibn Sina, Jakarta: UIN Jakarta Press, 2004.

,Filsafat Pendidikan Islam, Jakarta: Gaya Media Pratama, 2005.

,Pemikiran Pendidikan Islam dan Barat, Jakarta: PT Raja Grafindo Persada, 2013.

Nizar, Samsul dan Zainal Efendi Hasibuan. Hadits Tarbawi: Membangun Kerangka Pendidikan Ideal Perspektif Rasulullah saw, Jakarta: Kalam Mulia, 2011.

Qosim, Muhammad Jamaluddin. MauidhatulMu'minin Juz 2, Libanon: Darul Kitab Al-Islami, 2005.

Ramayulis. Ilmu Pendidikan Islam, Jakarta: Kalam Mulia, 2010 ,Metodologi Pengajaran Agama Islam, Jakarta: Kalam Mulia, 1990.

Salim, M. Haitami dan Syamsul Kurniawan. Studi Ilmu Pendidikan Islam, Jogyakarta: ar-Ruzz, 2012. 